\title{
PEMANFAATAN TEKNOLOGI SEBAGAI MEDIA PEMBELAJARAN DARING (ON LINE) BAGI GURU DAN SISWA DI SMK NU ROGOJAMPI
}

\author{
Mohamad Dimyati A'), Devit Suwardiyanto' ${ }^{2)}$, Herman Yuliandoko ${ }^{3)}$, Vivien Arief (4) \\ Program Studi Teknik informatika, Politeknik Negeri Banyuwangi \\ Jl. Raya Jember Km. 13, Labanasem, Kabat, Banyuwangi \\ e-mail: dimyati@poliwangi.ac.id 1),devit@poliwangi.ac.id²), \\ herman.yuliandoko@yahoo.com ${ }^{3}$,vivien.wardhany@gmail.com ${ }^{4)}$
}

\begin{abstract}
ABSTRAK
Pembelajaran merupakan hal yang utama dalam sebuah institusi pendidikan, sehingga proses pembelajaran yang baik akan menghasilkan lulusan yang baik pula. Namun demikian banyak temui sekolah-sekolah yang proses pembelajarannya masih konvensional dan salah satunya di SMK NU Rogojampi. Keadaan ini tentu saja perlu diperbaiki dengan meningkatkan sarana pembelajarannya untuk meningkatkan proses belajar mengajar. Oleh sebab itu melalui program pengabdian ini diharapkan dapat mendukung dan meningkatkan proses belajar mengajar di Mitra. Program bertujuan menerapkan pembelajaran daring (on line) dengan membangun sebuah portal e-learning untuk membantu proses belajar mengajar. Kegiatan pengabdian dilaksanakan dalam bentuk pelatihan penerapan pembelajaran daring menggunakan moodle sebagai aplikasi Learning Mangement Sytem (LMS). Target kegiatan ini adalah guru dan siswa di SMK NU Rogojampi dan luaran kegiatan penggunaan pembelajaran daring untuk meningkatan proses belajar mengajar.
\end{abstract}

Keywords - e-learning, SMK, Learning Mangement Syte,Moodle

\section{PENDAHULUAN}

Pemerintah melalui dinas pendidikan dan kebudayaan mengalakan pendidikan vokasional untuk memenuhi kebutuahan industri akan tenaga kerja yang profesional. Salah satu wujudnya adalah berdirinya Sekolah Menengah Kejuruan (SMK) dalam jumlah yang banyak. Sebagian SMK didirikan menggunakan sumber dana pemerintah dan sebagian lagi menggunakan dana masyarakat melalui yayasan. SMK NU Rogojampi merupakan sebuah SMK yang berdiri dibawah naungan yayasan Aswaja pada tahun 2014. Latar belakang berdirinya SMK NU Rogojampi adalah ingin berpartisipasi membangun bangsa, sebagai mana Program Pemerintah Republik Indonesia, melalui Kementerian Pendidikan Nasional, telah mencanangkan Program Pembangunan Nasional di bidang Pendidikan yang diarahkan untuk pemerataan dan perluasan akses pendidikan, peningkatan mutu, relevansi dan daya saing, penguatan tata kelola, akuntabilitas, dan pencitraan publik.

Penggunaan teknologi sebagai pendukung aktivitas manusia sudah tidak terelakan lagi, tanpa terkecuali pada bidang pendidikan. Sistem pembelajaran konvensional membutuhkan tempat untuk melakukan pertemuan pada waktu tertentu dirasa masih kurang dalam rangka meningkatkan kompentensi siswa. Kebutuhan akan diskusi dan penyampaian materi pada sistem konvensional mengharuskan guru dan siswa berada pada tempat dan waktu yang sama. Pemanfaatan teknologi untuk memudahkan dan mendukung proses belajar mengajar merupakan sebuah usaha untuk meningkatkan kompetensi siswa.

Sistem pembelajaran daring (on line) atau yang dikenal dengan istilah e-learning merupakan sebuah bentuk memanfaatkan teknologi untuk mendukung proses belajar mengajar. Pembelajaran daring memudahkan guru untuk memberikan materi dan diskusi setiap saat melalui jaringan internet. Disisi lain, 
memudahkan siswa untuk mengunduh materi maupun melakukan diskusi yang berkaitan dengan mata pelajaran yang ada. Selain itu pembelajaran daring juga mendukung untuk pelaksanaan ujian secara daring (on line). Dimana siswa ditutut untuk lebih mandiri dalam menjawab semua soal-soal ujian. Karena soal dalam ujian daring (on line) memungkinkan dilakukan pengacakan nomor urut dan urutan pilihan jawaban pada soal pilihan ganda. Hal ini dapat membantu siswa untuk mempersiapkan mental dan membisakan diri untuk menghadapi ujian nasional dengan metode Ujian Berbasis Komputer (UBK).

Beberapa manfaat penerapan pembelajaran daring (on line) yang dipadukan dengan sistem yang selama ini ada atau sistem konvensional dapat meningkatkan kompetensi dan memudah dalam melakukan kegiatan belajar mengajar. Dukungan berupa pengenalan dan pelatihan untuk menerapkan sistem pembelajaran daring mutlak diperlukan, baik itu bagi siswa dan guru

\section{TINJAUAN PUSTAKA}

Target dari kegiatan pelatihan dalam rangka program pengabdian kepada masyarakat ini adalah (1) Guru dan siswa di SMK NU Rogojampi dengan jumlah total peserta adalah 20 orang;(2) Semua Peserta dapat memahami sistem pembelajaran secara on line;(3) Guru dapat memahami tahapan dalam memberikan atau mengungah materi dan tugas ke server eLearning;(4) Siswa dapar memahami cara mengambil/ mengunduh materi atau tugas yang diberikan guru pada server e-Learning;(5) semua peserta mempunyai gambaran berkaitan dengan ujian secara on line.

Luaran yang dicapai adalah media pembelajaran daring (on line) bagi guru dan siswa SMK NU Rogojampi untuk meningkatkan proses belajar mengajar. Media yang digunakan adalah sebuah web hosting yang sudah terinstal aplikasi moodle sebagai sistem managemen untuk penerapan pembelajaran darin (on line). Alamat web hosting yang digunakan untuk sistem pembelajaran darin (on line) adalah https://elearnig.smknurogojampi.sch.id.

Kapasitas penyimpanan data sebesar 2 GB dengan lama sewa 1 tahun.

\section{METODE PELAKSANAAN}

Kegiatan pelatihan pembelajaran daring (on line) ini dilaksanakadengan tahapan-tahapan berikut:

A. Analisis Kebutuhan

Kegiatan pengabdian diawali dengan melakukan kunjungan dan komunikasi ke SMK NU Rogojampi untuk mendapatkan informasi yang berkaitan dengan pelatihan pembelajaran daring (on line). Informasi yang dibutuhkan diantara peserta pelatihan, perangkat komputer dan koneksi internet. informasi tersebut dibutuhkan untuk mentukan model sistem pembelajaran daring. berdasarkan informasi yang di dapat bahwa SMK NU Rogojampi sudah memenuhi syarat minimal untuk menbangun e-learning menggunakan koneksi internet.

B. Penyiapan media pembelajaran daring Untuk dapat membangun suatu portal eLearning diperlukan tempat atau server di Internet dan nama domain atau alamat (URL). Server berfungsi sebagai tempat untuk menaruh file-file dan aplikasi elearning sehingga dapat diakses melalui Internet dengan alamat tertentu (URL). Oleh karena itu, untuk membangun sistem pebelajaran daring memerlukan dua hal tersebut. Webhosting dan nama domain dapat diperoleh dengah melakukan sewa atau gratis. Pada kegiatan ini, Webhosting dan nama domain dilakukan dengan menyewa.

Selanjutnya melakukan instalasi software yang diperlukan pada pembelajaran daring. Portal e-Learning dibangun menggunakan salah satu perangkat Learning Management System (LMS) yang diberi nama Moodle. Moodle merupakan salah satu LMS open source yang banyak digunakan di dunia untuk membuat portal e-Learning terpadu. Beberapa fitur penunjang pembelajaran daring tersedia dalam suatu portal elearning. Fitur-fitur penting penunjang 
pembelajaran daring tersebut misalnya: tugas, quiz, komunikasi, kolaborasi, serta fitur utama yang dapat mengungah berbagai format materi pembelajaran.

C. Pelaksanaan Kegiatan

Pengabdian pada masyarakat ini diberikan dalam bentuk pelatihan yang dilaksanakan pada tanggal 21 Oktober 2017 dan 25 Oktober 2017 bertempat di Laboratorium Komputer SMK NU Rogojampi. Pelatihan diikuti oleh 20 perserta yang terdiri dari guru dan siswa. Pelaksanaan kegiatan pelatihan diberikan dalam bentuk ceramah, diskusi dan latihan dalam menjalankan moodle sebagai media pembelajaran on lin

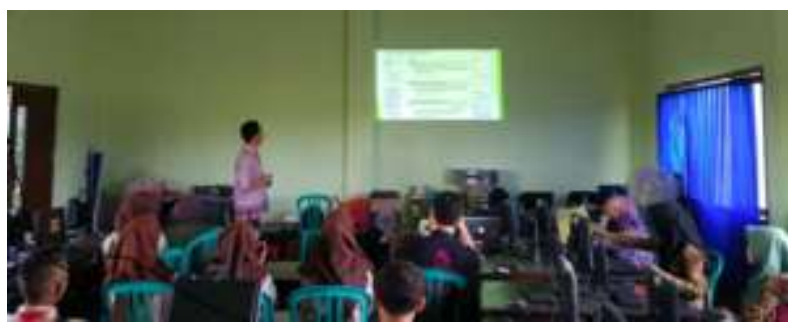

Gambar 1. Kegiatan Pelatihan Pembelajaran daring

\section{KELAYAKAN PERGURUAN TINGGI}

LPPM Politeknik Banyuwangi khususnya telah beberapa kali diberikan kepercayaan dan bekerjasama dengan pemerintah daerah khususnya PEMDA Banyuwangi. Ini sejalan dengan keinginan Politeknik Banyuwangi untuk berperan aktif dalam pembangunan daerah. Di tahun 2012, 2013, 2014 dan 2015 Politeknik Negeri Banyuwangi juga menjadi pusat pelatihan perangkat desa se-Kabupaten Banyuwangi dalam rangka komputerisasi perencanaan pembangunan daerah. Di tahun ini juga Politeknik Banyuwangi dilibatkan dalam penelitian potensi daerah khususnya BAPEDA dalam rangkan menyusun kebijaksanaan pemerintah daerah yang baik, tepat serta berdasarkan pada hasil sebuah penelitian yang mendalam.

Kegiatan pengabdian dilaksanakan oleg 4 orang yang mempunyai bidang kepakaran yang dibutuhkan untuk kegiatan pelatihan pembelajaran daring. Kegiatan ini membutuhkan bidang keparan Kepakaran dibidang sistem informasi dan e-Learning, kepakaran ini dibutuhkan dalam menyusun dan membuat sistem informasi dan e-Learning. Selain itu juga dibutuhkan bidang keparan dibidang jaringan, kepakaran ini dibutuhkan untuk mengkoneksikan e-Learning dalam bentuk intranet ataupun internet sehingga semua user dapat terlibat dalam sistem e-Learning.

\section{HASIL DAN LUARAN YANG DICAPAI}

Pengabdian pada masyarakat ini diberikan dalam bentuk pelatihan yang dilaksanakan pada tanggal 21 Oktober 2017 dan 25 Oktober 2017 bertempat di Laboratorium Komputer SMK NU Rogojampi. Pelatihan diikuti oleh 20 perserta yang terdiri dari guru dan siswa. Pelaksanaan kegiatan pelatihan diberikan dalam bentuk ceramah, diskusi dan latihan dalam menjalankan moodle sebagai media pembelajaran on line. Dimana moodle merupakan salah satu LMS (Learning Mangement Sytem) yang didistribusikan secara open source dan banyak digunakan sebagai sistem pembelajaran on line.

Kegiatan pelatihan e-Learning memberikan hasil sebagai berikut: (1) peserta dapat memahami sistem pembelajaran secara on line;(2) guru dapat memahami tahapan dalam memberikan atau mengungah materi dan tugas ke server e-Learning;(3) siswa dapar memahami cara mengambil materi atau tugas yang diberikan guru pada server eLearning.;(4)peserta dapat memahami pelaksanaan ujian secara on line dengan memanfaatkan berbagai fitur yang disediakan oleh moodle. Dimana saoal ujian dapat diberikan dalam pilihan ganda dengan system rondom atau esai;(5) guru dapat memahami cara melihat hasil atau nilai hasil ujian, terutama untuk soal ganda dan melihat bobot dari soal;(6) guru yang ditunjuk sebagai administrator system pembelajaran on line dapat menambahkan mata pelajaran dan account user sebagai guru dan siswa.

Sistem pembelajaran on line yang dibanggun sudah dapat di akses menggunakan jaringan internet. Sebuah server web hosting disewa selama 1 tahun dengan kapasitas data 2 GB yang 
beralamatkan

https://elearnig.smknurogojampi.sch.id. Pada gambar 2 merupakan tampilan dari web site elearning SMK NU Rogojampi yang dapat diakses menggunakan koneksi internet.

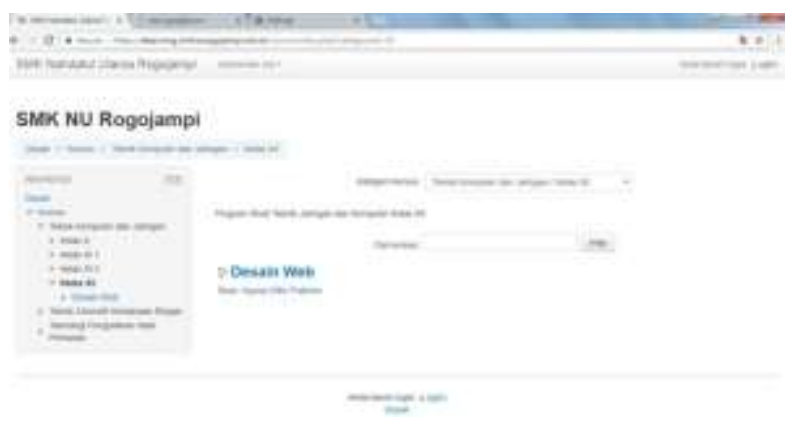

Gambar 2. Web site e-Learning SMK NU Rogojampi

Porta e-learning menggunakan moodle yang merupakan media pembelajaran daring sudah tersedia. Langkah selanjutnya adalah memberikan pelatihan kepada guru dan siswa untuk dapat mengoperasikan moodle. Adapun materi yang diberika pada pelatihan tersebut adalah:

A. Pengenalan tentang E learning dan Moodle Pengenalan e-learning memberikan pengetahuan kepada peserta yang berkaitan dengan e-learning, manfaat, kebutuhan peralatan dalam membangun e-learning. Peserta juga dijelaskan dengan moodle sebagai sebuah software yang digunakan untuk membangun e-learnig. fitur-fitur yang ada pada moodle juga merupakan pokok bahasan dalam tahapan ini.

B. Mengelola profil guru dan mata pelajaran Pada materi ini, peserta pelatihan terlebih dahulu mendapatkan materi tentang bagaimana pembuatan profil guru dan mata pelajaran masing-masing sesuai dengan mata pelajaran yang diampunya. Setelah itu, setiap peserta diminta untuk mempraktikkan secara mandiri.

C. Mengungah materi dan pembuatan tes

Peserta guru diberikan materi terlebih dahulu tentang cara mengungahmateri dan pembuatan soal dalam program moodle. Mengungah materi dapat menggunakan fasilitas up load maupun menggunakan fasilitas link dengan sumber materi yang tersedia. Peserta dilatih membuat soal dalam bentuk pilihan ganda, essay, atau benarsalah.

D. Mengelola user

Aplikasi moodle telah memberikan fitur untuk menambahkan user berdasarkan kelompok. Guru dikelompokan dalam teacher dan siswa dikelompkan dalam student. Gambar 4.5 menampilkan beberapa user yang sudah didaftarkan pada moodle. Setiap user mempunyai authentication berupa username dan password untuk login ke dalam e-learning. Setelah login, user ditampilkan beberapa mata pelajaran yang sedang diikuti. User dapat mengunduh materi, tugas atau mengikuti tes yang diadakan sesuai dengan mata pelajaran yang di tempuh.

\section{KESIMPULAN DAN SARAN}

Pelatihan pembelajaran daring yang dilaksanakan di SMK NU Rogojampi memberikan pemahaman kepada peserta manfaat dari penerapan pembelajaran daring untuk menunjang proses belajar mengajar di sekolahan. Media pembalajaran daring yang dibangun menggunakan aplikasi moodle memberikan fitur-fitur yang dapat mengakomodasi kebutuhan pembelajaran daring. Beberapa fitur yang disediakan moodle antara lain: tugas, ujian komunikasi, kolaborasi, serta fitur utama yang dapat mengungah berbagai format materi pembelajaran

Peserta pelatihan yang terdiri dari guru dan siswa dapat menjalankan aplikasi e-learning yang telah dibangun menggunakan webhosting yang beralamatkan web https: //elearnig.smknurogojampi.sch.id. Guru dapat mengungah beberapa materi, tugas dan tes sesuai dengan mata pelajaran yang diampu. Sementara siswa dapat mengunduh materi dan tugas yang diberikan oleh guru. Tersedianya aplikasi e-learning memudahkan sekolah untuk menjalankan tes atau ujian secara on line. 
Beberapa hal yang perlu dipertimbangkan lebih lanjut dalam menerapkan pembelajaran daring antara lain:(1) Tampilan pada e-Learning perlu diganti dengan memanfaatkan themes dari moodle yang lebih atraktif, untuk menarik setiap pengunjung e-learning;(2) Penggunaan server sekolahan dengan menggunakan IP public perlu direncanakan untuk memudahkan dalam perawatan e-learning. Keutungan meggunakan server sendiri diantaranya adalah: mengintegrasikan server proxy sebagai pintu masuk koneksi internet sekolahan dengan server e-learning memudahkan administrator dalam mengelola user e-learning;(3) Pelatiham $e$ learning berdampak besar jika hasil pelatihan ditindak lanjuti dengan mengaplikasikan hasil pelatihan.

\section{DAFTAR PUSTAKA}

Boko Susilo, Rusdi Efendi, Syafdi Maizora, 2017. Membangun Pembelajaran Berbasis Web (ELearning) Bagi Guru Sekolah Dasar Pinggiran Kecamatan Muara Bangkahulu Kota Bengkulu. Jurnal Pengabdian Masyarakat Indonesia, VOL. 1, NO. 1, pp. 01-05.

Edi Kurniawan, Rancang Bangun Aplikasi ELearning pada SMK Pembangunan Pacitan Berbasis Web, Amikom, Yogjakarta.

Evi Fuji Astuti, Rita Retnowati, Bibin Rubini, 2012, Implementasi Pembelajaran IPA Berbasis e-Learning di SMK Negeri 3 Bogor, Program Studi Pendidikan Biologi FKIP Universitas Pakuan, Bogor.

Muhamad Ali, Istanto WD, Sigit Y, Muhamad Munir, 2014, Studi Pemanfaatan e-Learning Sebagai Media Pembelajaran Guru Dan Siswa SMK Di Yogyakarta, Fakultas Teknik UNY, Yogjakarta.

Sandy Kosasi, 2015, Perancangan e-Learning untuk Meningkatkan Motivasi Belajar Guru dan Siswa, Seminar Nasional Pendidikan Teknik Informatika (SENAPATI 2015), hal 82-88, Yogjakarta.

Subakdo Eko Yulianto, 2011, Pengaruh Persepsi Kemudahan Dan Persepsi Kemanfaatan Terhadap Pemanfaatan e-Learning Dengan Model Tam Di SMK Muhammadiyah 3 Yogyakarta, Jurnal Bisnis: Teori dan Implikasi (JBTI), Vol.1, No.1, Februari 2011. 